\title{
THE EFFECT OF AN ACUTE DOSE OF BIOTIN AT THE PRE-IMPLANTATION STAGE AND ITS RELATION WITH FEMALE SEX STEROIDS IN THE RAT
}

\author{
P. K. Paul and P. N. Duttagupta \\ Department of Zoology, University of Delhi, Delhi-110007, India
}

Summary An acute dose of biotin (10 mg/100 g body weight) in two subcutaneous injections when given to a rat on day 1 and 2 of pregnancy, caused resorption of fetuses and placentae. Pregnancies under such biotin-treated conditions were maintained by continued estrogen or progesterone therapy. Biotin-treated pregnant rats failed to maintain normal levels of uterine weight, glycogen and protein as well as hepatic protein concomitantly with the loss of pregnancy. Estrogen therapy under such conditions improved all the parameters in these organs including the placenta, but progesterone therapy did not. Glucose-6-phosphate dehydrogenase (G-6-PD) activity in ovary, adrenal, liver and uterus was also reduced following biotin-induced loss of pregnancy which had been improved by estrogen or progesterone therapy. Nevertheless, estrogen was superior to progesterone in stimulating the enzyme activity in these organs excepting the adrenal. As far as the tissue response to biotin, estrogen or progesterone in the nonpregnant rat is concerned, biotin and progesterone exerted a suppressing effect on uterine glycogen and protein and also on liver protein, while estrogen stimulated them. Similarly, biotin and progesterone adversely affected G-6-PD activity in all the organs studied except the liver and adrenal. Estrogen stimulated the enzyme activity in all these organs but adrenal. The study suggests that the primary reason for an acute dose of biotininduced loss of pregnancy is blockage of estrogen production, which probably regulates endogenous progesterone secretion. The associated metabolic derangements are probably secondary to estrogen deficiency and are discussed.

It is well known that various symptoms of hypervitaminosis including abnormalities in reproductive function can occur due to excess intake of vitamins such as A and E. The B group of vitamins are, however, not known to cause hypervitaminosis. Nevertheless, it has recently been reported that an acute dose 
of biotin causes irregularities of the estrus cycle, atrophic changes in the ovary and resorption of fetuses and placentae of rats $(1,2)$. On the contrary, during the last days of pregnancy the requirement of biotin increases and the minimum daily need of the vitamin seems to be as high as $3 \mu \mathrm{g}$ per rat (3). The adverse effects of biotin deficiency on the reproductive capacity and general metabolism are well documented $(3,4)$. An adequate amount of biotin is essential for the maintenance of hepatic glycogen, protein and nucleic acid synthesis in biotin deficient male rats $(4,5)$. However, no attempt has as yet been made to relate these biotin-involved metabolic changes during pregnancy with the sex steroids.

Hence it was of interest to study the effects on an acute dose of biotin on pregnancy in relation to estrogen and progesterone.

\section{MATERIALS AND METHODS}

Colony bred Holtzman-strain female rats, approximately 3 months old, were mated with the same strain of males. Day 1 of pregnancy was determined in the morning the rat showed spermatozoa in its vaginal smear. Thus a total number of 32 pregnant rats were obtained. A dose of $10 \mathrm{mg}$ of $\mathrm{D}(+)$-biotin (E. Merck) dissolved in $0.2 \mathrm{ml}$ of $0.1 \mathrm{~N} \mathrm{NaOH}$ per $100 \mathrm{~g}$ of body weight was injected subcutaneously to 9 rats on Day 1 and 2 of pregnancy. The next batch of 7 pregnant rats was identically treated with biotin. and was also given $0.1 \mu \mathrm{g}$ of $17-\beta$-estradiol in $0.05 \mathrm{ml}$ of olive oil subcutaneously daily up to day 21 of pregnancy starting from day 6 . Yet another batch of 7 pregnant rats was treated with $4 \mathrm{mg}$ of progesterone in $0.2 \mathrm{ml}$ of olive oil in addition to biotin as in the other groups. The last batch of 9 pregnant rats served as untreated controls. Another batch of 18 nonpregnant rats was used for 21 days in 3 groups (6 rats in each) as non-pregnant-treated controls and were treated with the same dose of biotin, estradiol and progesterone as these were in the case of pregnant rats. Estrogen or progesterone treatment of these non-pregnant rats was given during the last 16 days of the experiment to maintain the total doses of the steroids uniform for both the non-pregnant and pregnant animals. Finally, 40 rats constituting 4 groups (10 rats each) served as normal controls at different stages of the estrus cycle, viz., pro-estrus, estrus, metaestrus and diestrus. The experiments on non-pregnant rats along with the pregnant ones were run to assess the tissue response to biotin and the steroids individually and to observe how these responses compare with the pregnant ones.

The animals were housed in an air-conditioned room under a 10:14 hour light-dark schedule, and were fed a standardized rat pellet commercially (Hindustan Lever Ltd.) prepared from natural food sources. According to the manufacturer's specifications the food contains $24 \%$ protein, $50 \%$ carbohydrate and $4 \%$ fat with adequate amount of vitamin mixture. The caloric value of the food was 3,200 per kilogram. 
Autopsies were performed on the morning of the $22 \mathrm{nd}$ day of experiments. The liver, ovaries, uterus, placentae and fetuses were removed and weighed. The initial and final body weight of all the rats were recorded. The final body weight of the pregnant rat was considered excluding foetuses, placentae and uterus.

Suitable pieces of the liver, uterus and placenta were processed for quantitative estimations of glycogen, RNA, DNA, and protein. MoNTGOMERY's (1957) (6) method was used for glycogen estimation. Tissue RNA, DNA and protein were extracted according to the method of SCHMIDT and THANNHAUSER (1945) (7) and measured quantitatively following the method of MERCHANT et al. (1958) (8), Burton (1965) (9) and Lowry et al. (1951) (10). The glucose-6-phosphate dehydrogenase activity of the ovary, adrenal, liver, uterus and placenta was measured according to the method of GLOCK and MCLEAN (1953) (11) and modified by HugGins and YAo (1959) (12).

\section{RESULTS}

\section{Effects on body and organ weights and pregnancy maintenance}

Following biotin treatment there was complete resorption of fetuses and placentae in 8 out of 9 rats (Table 1). Pregnancies under such conditions were maintained by continuing estrogen or progesterone therapy. Although the fetal and placental weights of estrogen or progesterone maintained biotintreated rats appeared to be lower than the controls, values were not statistically

Table 1. Effects of an acute dose of biotin on pregnancy maintenance and its relation with estrogen and progesterone in the rat.

\begin{tabular}{|c|c|c|c|c|}
\hline Treatment & $\begin{array}{l}\text { No. implanta- } \\
\text { tion sites }\end{array}$ & No. fetuses & $\begin{array}{c}\text { Fetal } \\
\text { weight (g) }\end{array}$ & $\begin{array}{r}\text { Placental } \\
\text { weight }(\mathrm{g})\end{array}$ \\
\hline & \multicolumn{4}{|c|}{ with fetuses (9)-none resorbed } \\
\hline $\begin{array}{l}\text { Untreated control } \\
\text { run for } 21 \text { days }\end{array}$ & $9.19 \pm 1.98$ & $\begin{array}{l}7.55 \pm 1.45 \\
\text { Without fetu }\end{array}$ & $\begin{array}{l}6.02 \pm 0.95 \\
-1 \text { with fetus }\end{array}$ & $0.602 \pm 0.153$ \\
\hline Biotin $^{a}$ & \multicolumn{4}{|c|}{ With fetuses (6)-1 resorbed } \\
\hline $\begin{array}{l}\text { Biotin }+0.1 \mu \mathrm{g} \\
\text { estradiol from day } \\
6-21\end{array}$ & $9.11 \pm 1.10$ & $\begin{array}{l}9.11 \pm 1.10 \\
\text { With fetuses }\end{array}$ & $\begin{array}{l}4.72 \pm 0.50 \\
\text { one resorbed }\end{array}$ & $0.482 \pm 0.075$ \\
\hline $\begin{array}{l}\text { Biotin }+4 \mathrm{mg} \\
\text { progesterone from } \\
\text { day } 6-21\end{array}$ & $9.29 \pm 1.71$ & $7.45 \pm 1.55$ & $3.54 \pm 0.90$ & $0.479 \pm 0.051$ \\
\hline
\end{tabular}

The figures in the parentheses indicate number of rats.

The animals were sacrificed on day 22 of pregnancy in the morning.

a $10 \mathrm{mg} / 100 \mathrm{~g}$ of body weight in 2 injections on day 1 and 2 of pregnancy. 
significant (Table 1). The biotin-treated pregnant rat after progesterone therapy showed normal body weight gain, but a maximum increase in body weight occurred following estrogen treatment along with pregnancy maintenance (Table 2). In contrast, progesterone was more potent in increasing body weight of the nonpregnant rat, while estrogen inhibited it completely. Biotin as such inhibited the normal body weight gain in both pregnant and nonpregnant rats. There were no significant changes in the weight of the liver and ovary of biotin-treated or

Table 2. Effects of an acute dose of biotin on body and organ weights in the pregnant and nonpregnant rat and its relation with estrogen and progesterone.

\begin{tabular}{|c|c|c|c|c|}
\hline Treatment & $\begin{array}{l}\text { ody weight (BW) } \\
\text { gain }(+) \text { or } \\
\text { loss }(-)(\mathrm{g})\end{array}$ & $\begin{array}{l}\text { Liver weight } \\
\mathrm{g} / 100 \mathrm{~g} \mathrm{BW}\end{array}$ & $\begin{array}{l}\text { Uterine weight } \\
\mathrm{mg} / 100 \mathrm{~g} \mathrm{BW}\end{array}$ & $\begin{array}{l}\text { Ovarian weight } \\
\mathrm{mg} / 100 \mathrm{~g} \mathrm{BW}\end{array}$ \\
\hline & \multicolumn{4}{|c|}{ Pregnant } \\
\hline & \multicolumn{4}{|c|}{ With fetuses (9) } \\
\hline \multirow[t]{2}{*}{$\begin{array}{l}\text { Untreated control } \\
\text { run for } 21 \text { days }\end{array}$} & $+37 \pm 4.6$ & $4.06 \pm 0.23$ & $1199.4 \pm 17.1$ & $24.5 \pm 2.1$ \\
\hline & & \multicolumn{2}{|c|}{ Without fetuses (8) } & \\
\hline \multirow[t]{2}{*}{ Biotin $^{\mathrm{a}}$} & $+26 \pm 4.0$ & $4.00 \pm 0.70$ & $266.2 \pm 15.0$ & $20.2 \pm 1.9$ \\
\hline & \multicolumn{4}{|c|}{ With fetuses (6) } \\
\hline \multirow[t]{2}{*}{$\begin{array}{l}\text { Biotin }+0.1 \mu \text { g estra- } \\
\text { diol for } 16 \text { days } \\
\text { from day } 6 \text { to } 21\end{array}$} & $+56 \pm 7.0$ & $4.14 \pm 0.50$ & $1271.6 \pm 30.9$ & $36.0 \pm 2.3$ \\
\hline & \multicolumn{4}{|c|}{ With fetuses (7) } \\
\hline \multirow[t]{2}{*}{$\begin{array}{l}\text { Biotin }+4 \text { mg pro- } \\
\text { gestrone for } 16 \text { days } \\
\text { from day } 6 \text { to } 21\end{array}$} & $+37 \pm 12.0$ & $3.90 \pm 0.65$ & $1083.5 \pm 12.1$ & $26.2 \pm 1.7$ \\
\hline & \multicolumn{4}{|c|}{ Non-pregnant } \\
\hline \multicolumn{5}{|l|}{$\begin{array}{l}\text { Untreated control } \\
\text { run for } 21 \text { days: }\end{array}$} \\
\hline Proestrus & & $3.39 \pm 0.15$ & $169.9 \pm 8.6$ & $27.2 \pm 5.4$ \\
\hline Estrus & $+17.0 \pm 1.1(10 \times 4)$ & $3.54 \pm 0.19$ & $219.9 \pm 18.9$ & $31.6 \pm 5.4$ \\
\hline Metaestrus & & $3.39 \pm 0.11$ & $168.9 \pm 6.6$ & $24.6 \pm 1.4$ \\
\hline Diestrus & & $3.71 \pm 0.19$ & $134.4 \pm 19.1$ & $23.1 \pm 1.3$ \\
\hline Biotin $^{2}$ & $+6.7 \pm 3.3(6)$ & $3.53 \pm 0.02$ & $206.1 \pm 17.5$ & $26.4 \pm 2.7$ \\
\hline $\begin{array}{l}0.1 \mu \mathrm{g} \text { estradiol } \\
\text { for } 16 \text { days }\end{array}$ & $-5 \pm 1.8(6)$ & $3.26 \pm 0.18$ & $225.1 \pm 16.5$ & $28.5 \pm 2.8$ \\
\hline $\begin{array}{l}4 \mathrm{mg} \text { progesterone } \\
\text { for } 16 \text { days }\end{array}$ & $+30 \pm 6.9(6)$ & $3.75 \pm 0.15$ & $103.3 \pm 2.3$ & $19.6 \pm 2.7$ \\
\hline
\end{tabular}

The figures in parentheses indicate number of rats. The pregnant rats were sacrificed on day 22 of pregnancy in the morning. The body weight was considered excluding fetuses, placentae and uterus.

a $10 \mathrm{mg} / 100 \mathrm{~g}$ body weight in 2 injections on day 1 and 2 of pregnancy or the experimental period. Estradiol or progesterone was given during the last 16 days of the experimental period. 
biotin followed by estrogen or progesterone-treated rats irrespective of the maintenance or no maintenance of pregnancy (Table 2). The uterine weight was significantly $(p<0.001)$ reduced after biotin treatment along with loss of pregnancy, but in the nonpregnant rat, biotin did not induce reduction of uterine

Table 3. Effects of an acute dose of biotin on tissue glycogen and blood glucose levels in the pregnant and non-pregnant rat and its relation with estrogen and progesterone.

\begin{tabular}{|c|c|c|c|c|c|}
\hline \multirow{3}{*}{ Treatment } & \multicolumn{4}{|c|}{ Glycogen (mg/100 mg tissue) } & \multirow{3}{*}{$\begin{array}{c}\text { Blood glucose } \\
\text { mg/100 ml } \\
\text { blood }\end{array}$} \\
\hline & Liver & Ut & us & Placenta & \\
\hline & & $\begin{array}{l}\text { With } \\
\text { implantation } \\
\text { site }\end{array}$ & $\begin{array}{l}\text { Without } \\
\text { implantation } \\
\text { site }\end{array}$ & & \\
\hline
\end{tabular}

\begin{tabular}{|c|c|c|c|}
\hline & \multicolumn{3}{|c|}{ Pregnant } \\
\hline & \multicolumn{3}{|c|}{ With fetuses (9) } \\
\hline $\begin{array}{l}\text { Untreated con- } \\
\text { trol run for } \\
21 \text { days }\end{array}$ & $1.34 \pm 0.168 \quad 0.565 \pm 0.084$ & $0.269 \pm 0.010 \quad 0.387 \pm 0.063$ & $134.0 \pm 16.8$ \\
\hline
\end{tabular}

\begin{tabular}{|c|c|c|c|c|c|}
\hline \multirow{3}{*}{ Biotin $^{2}$} & \multicolumn{5}{|c|}{ Without fetuses (8) } \\
\hline & $1.14 \pm 0.058$ & $0.248 \pm 0.010$ & - & - & $119.0 \pm 3.5$ \\
\hline & \multicolumn{5}{|c|}{ With fetuses (6) } \\
\hline $\begin{array}{l}\text { Biotin }+0.1 \mu \mathrm{g} \\
\text { estradiol for } 16 \\
\text { days from day } \\
6-21\end{array}$ & $1.21 \pm 0.073$ & $0.395 \pm 0.013$ & $0.195 \pm 0.027$ & $0.340 \pm 0.072$ & $133.0 \pm 3.9$ \\
\hline
\end{tabular}

With fetuses (7)

Biotin $+4 \mathrm{mg}$ progesterone for 16 days from day $6-21$

\begin{tabular}{|c|c|c|c|c|c|}
\hline \multirow{3}{*}{$\begin{array}{l}\text { Untreated control: } \\
\text { Proestrus }\end{array}$} & \multicolumn{5}{|c|}{ Non-pregnant } \\
\hline & \multicolumn{2}{|l|}{ : } & & \multirow{2}{*}{$\div$} & \multirow[b]{2}{*}{$122.3 \pm 4.0$} \\
\hline & $0.715 \pm 0.103(10)$ & - & $0.153 \pm 0.014$ & & \\
\hline Estrus & $1.36 \pm 0.105(10)$ & - & $0.302 \pm 0.026$ & - & $133.3 \pm 3.5$ \\
\hline Metaestrus & $0.899 \pm 0.049(10)$ & - & $0.146 \pm 0.017$ & - & $125.0 \pm 2.7$ \\
\hline Diestrus & $1.000 \pm 0.110(10)$ & - & $0.108 \pm 0.010$ & - & $164.0 \pm 3.9$ \\
\hline Biotin $^{a}$ & $1.13 \pm 0.093(6)$ & - & $0.116 \pm 0.005$ & - & $106.0 \pm 7.7$ \\
\hline $\begin{array}{l}0.1 \mu \mathrm{g} \text { estradiol } \\
\text { for } 16 \text { days }\end{array}$ & $0.350 \pm 0.050$ ( 6) & - & $0.250 \pm 0.030$ & - & $160.0 \pm 4.3$ \\
\hline $\begin{array}{l}4 \mathrm{mg} \text { progesterone } \\
\text { for } 16 \text { days }\end{array}$ & $0.648 \pm 0.041(6)$ & - & $0.066 \pm 0.009$ & - & $135.0 \pm 5.0$ \\
\hline
\end{tabular}

The figures in parentheses indicate number of rats. The animals were sacrificed on the 22 nd day of the experiment in the morning.

a $10 \mathrm{mg} / 100 \mathrm{~g}$ body weight in two injections on day 1 and 2 of the experimental period. Estradiol or progesterone was given during the last 16 days of the experiment. 
weight (Table 2). Estrogen treatment of these biotin pre-treated pregnant rats maintained the normal pregnancy level of uterine weight, while following progesterone treatment the uterine weight was significantly $(p<0.01)$ lower than those of untreated pregnant controls. A similar type of response in the uterine weight to estrogen or progesterone was observed in the nonpregnant rat.

\section{Effects on tissue glycogen and blood glucose}

The hepatic glycogen concentration of pregnant rats remained unchanged following biotin or biotin plus estrogen or progesterone treatment (Table 3). In the nonpregnant rat also biotin did not affect the liver glycogen, but continued estrogen treatment for 16 days caused a maximum reduction of the hepatic glycogen concentration. On the other hand, a significant $(p<0.01)$ reduction in glycogen concentration occurred in the uterus with implantation sites after biotin treatment along with the loss of pregnancy (Table 3). Under such conditions estrogen treatment maintained uterine (with implantation site) glycogen at a level comparable with those of controls, but progesterone treatment had no effect. In the nonpregnant rat also biotin maintained the uterine glycogen at a level comparable with that of diestrous stage of the cycle, while estrogen raised it to the estrus level, but progesterone further reduced it to lower than that of diestrus level. The placental glycogen level of the biotin pre-treated rat, too was more responsive to estrogen than that of progesterone-treated rat (Table 3). The blood glucose level of the pregnant rat was not reduced significantly after biotin treatment, but compared with the level in the diestrus stage, which was highest, significant $(p<0.01)$ reduction of the blood glucose occurred in the biotintreated nonpregnant rat (Table 3). Estrogen or progesterone treatment of the biotin pre-treated pregnant or normal nonpregnant rat showed blood glucose levels comparable with those of untreated-pregnant or diestrus-level rats.

\section{Effects on tissue RNA, DNA and protein}

The hepatic RNA concentration was reduced $(p<0.05)$ in the biotin-treated pregnant rat, but the uterine level of RNA remained unaffected (Table 4). Under such conditions estrogen treatment maintained hepatic RNA at a level comparable with that of untreated pregnant control, while the liver did not respond to progesterone significantly. The uterine RNA, however, increased beyond the control level following estrogen treatment; there was no effect with progesterone. In the cycling rat, hepatic and uterine RNA concentration was highest in the estrus stage. The biotin-treated nonpregnant rat maintained hepatic RNA at a level comparable with those of controls at pro-estrus, metaestrus and diestrus stages of the cycle. Uterine RNA concentration following biotin treatment, however, was maintained at the lowest level which was comparable with that of the diestrus level of the normal control. Estrogen treatment could maintain the hepatic and uterine RNA level as these were in the estrus stage, but progesterone inhibited 
RNA accumulation in these organs. The protein concentration of both the liver and uterus showed a marked $(p<0.001)$ reduction after biotin treatment of the pregnant rat (Table 4). Estrogen treatment of the biotin-treated rats restored the uterine protein levels from the biotin-induced depletion. Although the liver protein of the biotin pre-treated rat increased to a large extent following estrogen treatment, still it was lower than the control value. Progesterone treatment failed to induce any significant influence on the liver and uterine protein concentration in the biotin pre-treated rat. A similar trend showing the stimulatory effect of estrogen and inhibitory effect of progesterone on tissue RNA and protein was also noticed in the placenta, uterus and liver of the nonpregnant rat. A significant $(p<0.01)$ increase in DNA concentration occurred in the biotintreated pregnant rat that lost pregnancy only in the uterus. Estrogen or progesterone therapy was able to maintain DNA at a level comparable with that of the normal pregnant control (Table 4). On the other hand, DNA concentration of the uterus of the nonpregnant rat was more effective on estrogen or estrus condition. Both biotin and progesterone treatment caused reduction of the DNA level of the uterus in comparison with that of estrous stage of the control. The placental DNA level of the biotin pre-treated rat was not effective by estrogen or progesterone treatment.

\section{Effects on tissue glucose-6-phosphate dehydrogenase activity}

The glucose-6-phosphate dehydrogenase (G-6-PD) activity in the ovary, adrenal, liver and uterus was significantly $(p<0.001)$ reduced after biotin treatment of the pregnant rat (Table 5). Estrogen or progesterone administration to the biotin pre-treated rats induced significant $(p<0.01)$ improvement in the enzyme activity in all of these organs over only biotin-treated rats. Nevertheless, neither of these steroids was able to restore the normal activity of the enzyme in these organs excepting uterus and placenta. Moreover, progesterone appeared to be less active in this regard than estrogen excepting in the adrenal. In the nonpregnant rat, the G-6-PD activity in the ovary and uterus reached its peak at the estrus stage, while the peak in the adrenal was reached at the diestrus stage of the cycle. The liver G-6-PD activity did not show significant variations during estrus cycle. Biotin treatment caused a significant $(p<0.001)$ reduction of the G-6-PD activity in the uterus as compared to any stage of the cycle. The ovarian and adrenal activity of the enzyme after biotin treatment was maintained at a level comparable with those of diestrus and estrus levels of the controls respectively, while the enzymeactivity in the liver compared with that of other stages of the cycle showed an increase. Continued estrogen treatment of the nonpregnant rat did not maintain the ovarian G-6-PD activity as it was in the estrus stage, but the uterine enzyme activity was maintained. On the other hand, progesterone stimulated G-6-PD activity only in the adrenal. 
P. K. PAUL and P. N. DUTTAGUPTA

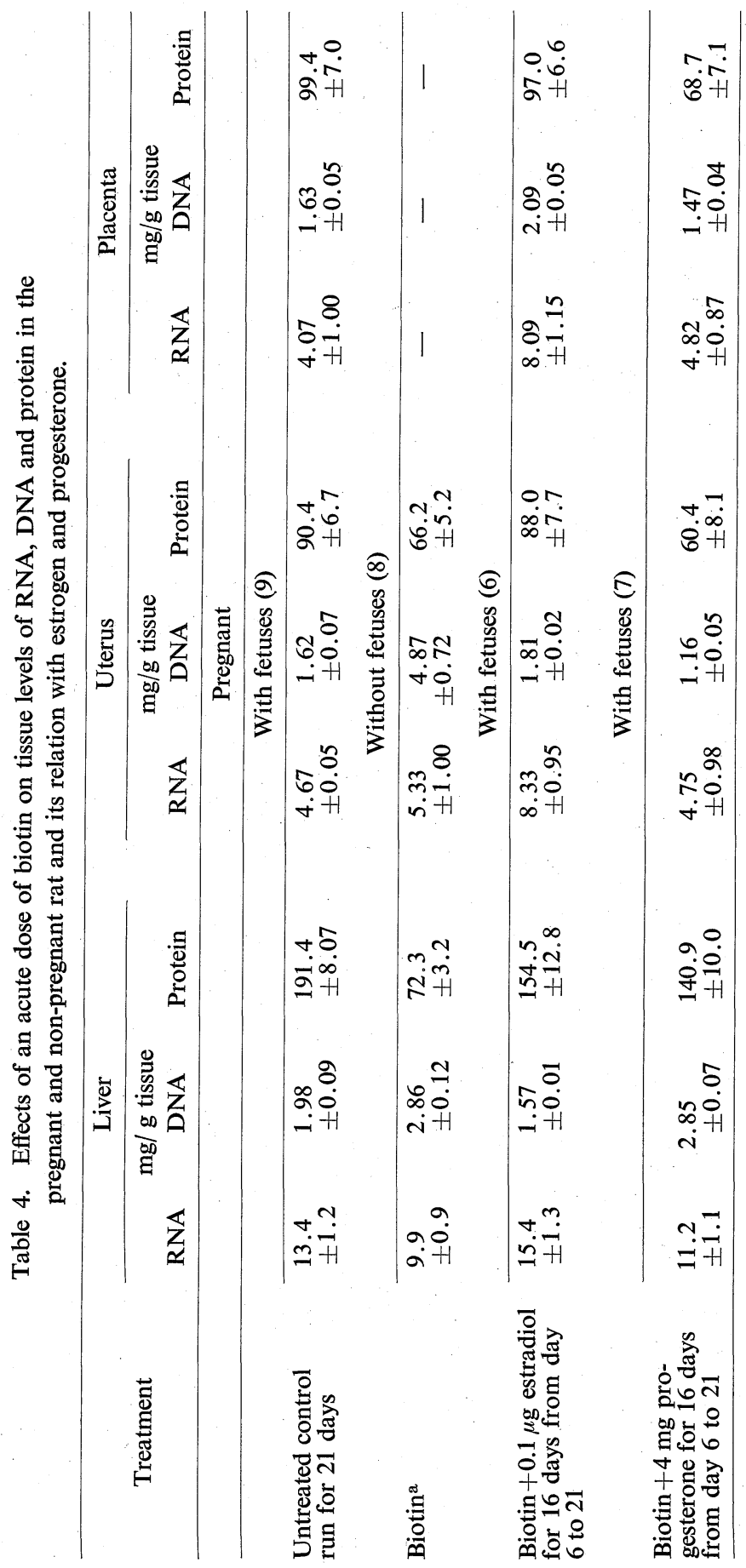




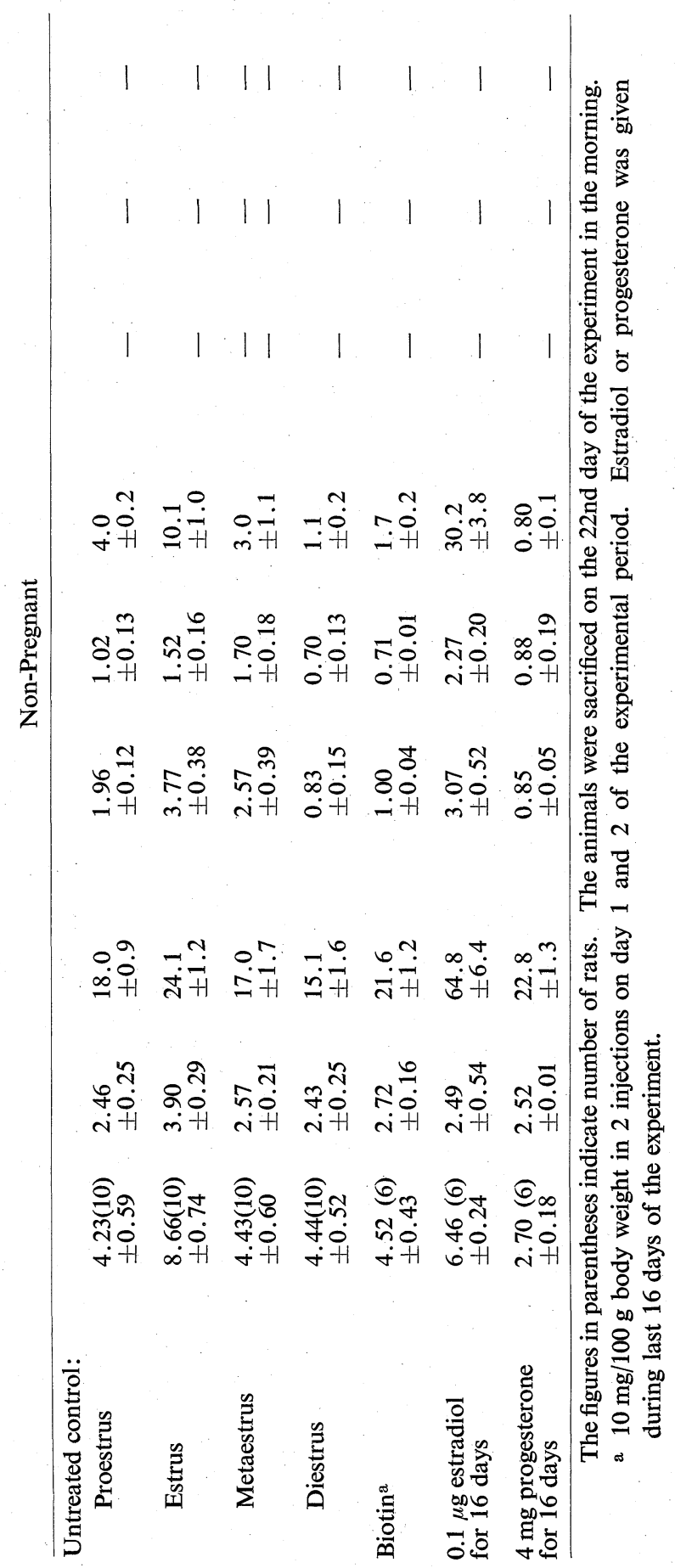


Table 5. Effects of an acute dose of biotin on tissue glucose-6-phosphate dehydrogenase activity and its relation with estrogen and progesterone.

\begin{tabular}{|c|c|c|c|c|c|}
\hline \multirow[t]{3}{*}{ Treatment } & \multicolumn{5}{|c|}{$\begin{array}{l}\text { Glucose-6-phosphate dehydrogenase activity } \\
\text { mM TPNH/100 mg tissue/min at room temperature }\end{array}$} \\
\hline & Ovary & Adrenal & Liver & Uterus & Placenta \\
\hline & \multicolumn{5}{|c|}{ Pregnant } \\
\hline \multirow{3}{*}{$\begin{array}{l}\text { Untreated control } \\
\text { run for } 21 \text { days }\end{array}$} & \multicolumn{5}{|c|}{ With fetuses (6) } \\
\hline & $138.0 \pm 6.0$ & $195.0 \pm 8.0$ & $156.0 \pm 5.0$ & $73.0 \pm 4.0$ & $68.0 \pm 5.2$ \\
\hline & \multicolumn{5}{|c|}{ Without fetuses (6) } \\
\hline \multirow[t]{2}{*}{ Biotin $^{a}$} & $50.4 \pm 2.1$ & $90.0 \pm 4.1$ & $83.1 \pm 5.0$ & $20.5 \pm 1.5$ & 一 \\
\hline & \multicolumn{5}{|c|}{ With fetuses (6) } \\
\hline \multirow[t]{2}{*}{$\begin{array}{l}\text { Biotin }+0.1 \mu \mathrm{g} \text { estradiol } \\
\text { for } 16 \text { days from day } 6-21\end{array}$} & $122.0 \pm 8.0$ & $129.0 \pm 11.0$ & $138.0 \pm 10.0$ & $82.5 \pm 4.3$ & $72.0 \pm 6.0$ \\
\hline & \multicolumn{5}{|c|}{ With fetuses (6) } \\
\hline \multirow[t]{2}{*}{$\begin{array}{l}\text { Biotin }+4 \text { mg proge- } \\
\text { sterons for } 16 \text { days } \\
\text { from day } 6-21\end{array}$} & $101.7 \pm 15.3$ & $138.0 \pm 14.0$ & $120.0 \pm 8.0$ & $62.0 \pm 6.0$ & $54.0 \pm 9.0$ \\
\hline & \multicolumn{5}{|c|}{ Non-pregnant } \\
\hline \multicolumn{6}{|l|}{ Untreated Control: } \\
\hline Proestrus & $112.2 \pm 3.2(8)$ & $129.0 \pm 3.0$ & $80.8 \pm 3.2$ & $55.6 \pm 2.5$ & - \\
\hline Estrus & $174.5 \pm 6.2(8)$ & $145.0 \pm 2.0$ & $89.1 \pm 5.9$ & $82.3 \pm 2.7$ & - \\
\hline Metaestrus & $89.5 \pm 2.5(8)$ & $170.9 \pm 5.7$ & $101.3 \pm 8.2$ & $81.0 \pm 4.0$ & - \\
\hline Diestrus & $77.4 \pm 1.6(8)$ & $257.8 \pm 8.2$ & $102.3 \pm 6.5$ & $64.5 \pm 1.5$ & - \\
\hline Biotin $^{\mathrm{a}}$ & $77.8 \pm 3.1(6)$ & $154.1 \pm 8.3$ & $134.6 \pm 6.7$ & $24.5 \pm 2.8$ & - \\
\hline $\begin{array}{l}0.1 \mu \mathrm{g} \text { estradiol } \\
\text { for } 16 \text { days }\end{array}$ & $89.6 \pm 3.2(6)$ & $140.9 \pm 3.1$ & $103.2 \pm 2.8$ & $82.6 \pm 4.6$ & - \\
\hline $\begin{array}{l}4 \text { mg progesterone } \\
\text { for } 16 \text { days }\end{array}$ & $80.8 \pm 1.5(6)$ & $193.2 \pm 4.5$ & $106.1 \pm 5.5$ & $51.9 \pm 1.2$ & - \\
\hline
\end{tabular}

The figures in parentheses indicate number of rats. The animals were sacrificed on the 22nd day of the experiment in the morning.

a $10 \mathrm{mg} / 100 \mathrm{~g}$ body weight in 2 injections on day 1 and 2 of the experimental period.

Estradiol or progesterone was given during the last 16 days of the experiment.

\section{DISCUSSION}

The present study clearly demonstrates that an acute dose $(10 \mathrm{mg} / 100 \mathrm{~g}$ body weight) of biotin treatment before implantation, although it does not interfere with implantation processes, prevents development of fetuses and placentae. Pregnancies under such conditions are maintained by the administration of estrogen or progesterone. Recently, it has been reported from our laboratory that even an acute dose of $5 \mathrm{mg} / 100 \mathrm{~g}$ body weight of biotin causes irregularities of the estrus cycle with heavy leucocyte infiltration in the vagina and atrophy of the ovary (1). In spite of these disorders in the reproductive system, biotin- 
treated rats are able to maintain pregnancy up to day 14 following successful mating, but fetuses and placentae are subsequently resorbed (2). Estrogen therapy under such conditions supports pregnancy maintenance up to term. Therefore, it is clear from the present result that an acute dose of biotin blocks endogenous estrogen production by some unknown means. Previously it has been suggested that continued presence of estrogen is probably required for ovarian progesterone secretion during pregnancy $(13,14)$. This report concerning maintenance of pregnancy by continued estrogen or progesterone therapy to the biotin pretreated rat seems to support the proposed view indirectly.

The analysis of tissue glycogen concentration shows that the uterine glycogen is adversely affected by the acute dose of biotin both in the pregnant and nonpregnant conditions which can be stimulated by estrogen administration. Progesterone however, aggravates uterine glycogen deposition. The placental glycogen level on the last day of pregnancy in the biotin pre-treated rat is maintained by estrogen therapy as it is in the untreated control, but progesterone fails to do so. It is known that rat placental glycogen reaches its peak on day 16 and declines by day twenty-one (15). The maintenance of pregnancy in the biotin treated rat by estrogen or progesterone therapy, therefore, is associated with the natural decline of placental glycogen at term. It has been well established that estrogen and pregnancy induce glycogen accumulation in the uterus and liver, but progesterone is known to exert glycogenolytic effects in these organs and it also causes hyperglycemia (16-18), yet essential for pregnancy maintenance.

The study on the nucleic acid and protein, like glycogen also shows that biotin significantly reduces hepatic and uterine protein and RNA concentration both in the pregnant and nonpregnant rat. On the contrary, biotin deficiency reduces synthesis of hepatic glycogen, RNA and protein in the male rat, which can be corrected by insulin or biotin administration $(4,5)$. Estrogen administration to the biotin-treated pregnant rat restores the normal pregnancy levels of RNA and protein in these tissues. The normal nonpregnant rat uterus and liver similarly respond to estrogen. However, progesterone does not rectify biotininduced depletion of protein and RNA in the liver and uterus of the pregnant rat. Moreover, progesterone aggravates these parameters when administered to the cycling rat. It is known that during normal pregnancy in the rodent, total RNA, DNA and protein increase in the uterus, placenta and liver (19-21). Estrogen induces an increase in protein and nucleic acids synthesis in the uterus (22-24), and liver (25) of the nonpregnant rat. Therefore, it appears that estrogen plays a very important role in carbohydrate and protein metabolism during pregnancy. The mechanism through which progesterone operates in bringing about pregnancy maintenance is an open question. It has been suggested that progesterone alone or together with estrogen may maintain pregnancy in the absence of dietary protein by sustaining placental function $(26,27)$.

Regarding glucose-6-phosphate dehydrogenase (G-6-PD) activity in the ovary 
adrenal, liver and uterus, the results show that after a high dose of biotin treatment, the enzyme activity is significantly reduced in all of these organs. MISTRY and DAKSHINAMURTI (1964) (4), however, observed an increased activity of G-6-PD in the liver of biotin-deficient rats which is considered to be due to reduced availability of glucose-6-phosphate for metabolism. MCKERNS (1965) (28) has observed that ovarian G-6-PD activity of the rat is about twice as high during estrus as during diestrus. LunAAS et al. (1968) (29) reported that rat ovarian G-6-PD shows its highest activity during cycle, at parturition and after weaning, but that during pregnancy its activity is low. The present data is in agreement with the findings of MCKERNs (1965) (28) and LunAAs et al. (1968) (29) regarding G-6-PD activity in the ovary during cycle and pregnancy. GLOCK and MCLEAN (1953) (11) first noted a markedly higher activity of G-6-PD in the liver of the female rat as compared with that of the male. Subsequently HugGins and YAO (1959) (12) have observed that estrogen increases the enzyme activity in the liver of ovariectomized and adrenalectomized female and castrated male rat. On the other hand, adrenal G-6-PD activity is enhanced by ovariectomy and depressed by estrogen replacement (30). The present data show that although both estrogen and progesterone therapy to the biotin-treated pregnant rat improve G-6-PD activity in all of the organs studied, estrogen is more potent than progesterone in this regard except in the adrenal. In the non-pregnant rat also either estrus condition or estrogen treatment induces high level of activity of this enzyme in the ovary and uterus. The adrenal G-6-PD activity, unlike other organs appears to be more responsive to progesterone and diestrus condition, while estrogen administration and proestrus or estrus stage exhibit lowest activity of the enzyme. It is well known that pentose phosphate cycle which is initiated by G-6-PD provides the cell with essential NADPH for synthetic and reductive purposes and pentose sugar for nucleotide synthesis. The relatively low activity of G-6-PD in tissues is of considerable interest since the enzyme occupies a key position at a branching point of glucose metabolism by competing for glucose6-phosphate which is also the substrate for the isomerase giving rise to fructose6-phosphate and subsequent glycolysis via the Embden-Myerhof pathway. Low activity of G-6-PD would thus tend to favour glycolysis. Therefore, the reduction of G-6-PD activity following excess of biotin treatment, as observed perhaps indicates that the cellular synthetic mechanisms regulated by the pentose phosphate pathway are adversely affected by this vitamin excess.

However, the loss of pregnancy after biotin treatment as reported here does not seem to be due to reduction of tissue glycogen, protein and nucleic acid concentration and G-6-PD activity. Because progesterone alone supports pregnancy maintenance in biotin-treated rats without maintaining normal tissue levels of these biochemical parameters. It seems possible, therefore, that if critical levels of total available glycogen and protein (in relation to the weight of the organ) and activities of the enzymes involved in carbohydrate and protein metabolism are 
maintained in tissues, then progesterone in its own right can support maintenance of pregnancy.

From the present state of knowledge it appears that the primary reason for an acute excess of biotin-induced infertility in the rat is blockage of estrogen production which probably regulates endogenous secretion of progestins. The associated metabolic derangements, as discussed are probably secondary to estrogen deficiency.

\section{REFERENCES}

1) Paul, P. K., Duttagupta, P. N., and Agarwal, Hari C., Curr. Sci., 42, 185 (1973).

2) Paul, P. K., Duttagupta, P. N., and Agarwal, Hari C., Curr. Sci., 42, 613 (1973).

3) Terroine, T., in R. S. Harris, and D. J. Ingle (Editors), Vitamins and Hormones, Academic Press, New York \& London, Vol. 18, p. 1 (1960).

4) Mistry, S. P. and Dakshinamurti, K., in R. S. Harris, I. G. Wool and J. A. Loraine (Editors), Vitamins and Hormones, Academic Press, New York \& London, Vol. 22, p. 1 (1964).

5) Nicol, B., Nutrition Rev., 4, 93 (1971).

6) Montgomery, R., Arch. Biochem. Biophys., 67, 378 (1957).

7) Schmidt, G. and Thannhauser, S. J., J. Biol. Chem., 161, 83 (1945).

8) Merchant, D. J., Raymond, H. K., and MurPhy, W. H., Jr., in Handbook of Cell and Organ Culture, Burgess Publishing Co., Minneapolis, p. 263 (1958).

9) Burton, K., Biochem J., 62, 315 (1965).

10) Lowry, O. H., Rosebrough, N. J., Farr, A. L., and Randall, R. J., J. Biol. Chem., 193, 265 (1951).

11) Glock, G. E. and McLean, P., Biochem. J., 55, 400 (1953).

12) Huggins, C. and Yao, F., J. Exper. Med., 110, 899 (1959).

13) Paul, P. K., Endokrinologie, 57, 348 (1971).

14) Paul, P. K., Acta Endocr., 71, 385 (1972).

15) Hazelwood, R. L. and Nelson, M. M., Endocrinology, 77, 999 (1965).

16) Paul, P. K. and Duttagupta, P. N., Acta Endocr., 72, 762 (1973).

17) Fotherby, K., in R. S. Harris, I. G. Wool, and J. A. Loraine (Editors), Vitamins and Hormones, Academic Press, New York \& London, Vol. 22, p. 153 (1964).

18) YANG, M. M. P., Endocrinology, 86, 924 (1970).

19) Drasher, M. L., J. Expr. Zool., 122, 385 (1953).

20) Poo, L., Lew, W., and Addis, T., J. Biol. Chem., 128, 69 (1939).

21) Campbell, R. M., InNes, I. R., and Costerlitz, H. W., J. Endocr., 9, 52 (1953).

22) Noall, M. W. and Allen, W. M., J. Biol. Chem., 236, 2987 (1961).

23) Mueller, G. C., in Biological activities of Steroids in relation to Cancer, Academic Press, New York, p. 129 (1960).

24) Brody, S. and WiQvist, N., Endocrinology, 68, 971 (1961).

25) Song, C. S. and Kappas, A., in R. S. Harris and D. J. Ingle (Editors), Vitamins and Hormones, Academic Press, New York \& London, Vol. 26, p. 147 (1968).

26) Kendall, K. and Hays, R., J. Nutrition, 70, 10 (1960).

27) Fisher, C. J. and LeATHEM, J. H., Endocrinology, 76, 454 (1965).

28) McKerns, K. W., Biochem. Biophys. Acta, 97, 542 (1965).

29) LunaAs, T., Baldwin, R. L., and CupPs, P. T., Acta Endocr., 58, 521 (1968).

30) KITAY, J. I., in K. W. McKerns (Editor), Functions of The Adrenal Cortex, AppletonCentury Crofts, A division of Meredith Corp., New York, Vol. 2, p. 775 (1968). 